Article

\title{
Low-End Probabilistic Sea-Level Projections
}

\author{
Gonéri Le Cozannet* ${ }^{*}$, Rémi Thiéblemont, Jeremy Rohmer, Déborah Idier, \\ Jean-Charles Manceau and Robin Quique \\ BRGM, French Geological Survey, 3 Avenue Claude Guillemin, 45060 Orléans CEDEX, France \\ * Correspondence: g.lecozannet@brgm.fr
}

Received: 13 June 2019; Accepted: 17 July 2019; Published: 20 July 2019

check for updates

\begin{abstract}
In the area of sea-level rise, recent research has focused on assessing either likely or high end future sea levels, but less attention has been given to "low-end" sea-level projections, exploring best-case potential sea-level changes and providing the basis for estimating minimum adaptation needs. Here, we provide global and regional probabilistic sea-level projections using conservative projections of glaciers and ice-sheets melting and a selection of models from the Coupled Model Intercomparison Project phase 5 (CMIP5) delivering moderate thermal expansion. Our low-end sea-level projections are higher than previously estimated because they rely on modeling outcomes only, and do not add any expert judgement, aiming essentially at delivering more realistic upper tails. While there are good reasons to believe that our projections are excessively optimistic, they can be used as low-end sea-level projections in order to inform users with low aversion to uncertainty. Our low-end sea-level projection exceeds $0.5 \mathrm{~m}$ along most inhabited coasts by 2100 for business as usual greenhouse gas emissions (RCP8.5), which is relevant for adaptation practitioners as long as efficient climate change mitigation policies are not implemented. This means that without efficient climate mitigation, an acceleration of sea-level rise can hardly be avoided during the 21st century.
\end{abstract}

Keywords: sea-level rise; projections; probabilistic

\section{Introduction}

Sea-level rise is one of the consequences of the current climate warming induced by anthropogenic greenhouse gas emissions [1]. Specifically, sea-level rise is due to the following processes [1-3]: First, the warming of the ocean triggers thermal expansion [2,4] and increased melting of marine ice-sheets and glaciers, especially in Antarctica [5-7]. Second, the warming of the atmosphere increases surface melting on glaciers and Greenland [8-10]. Third, changes in precipitations modify the surface mass balance of the cryosphere [11,12]. Fourth, cascading impacts resulting from the previous processes, such as the increased velocity of glaciers after removal of ice shelves in Antarctica, also contribute to more rapid sea-level rise [13]. Finally, the extraction of groundwater is expected to become a net contribution to sea-level rise in the future, although it has been so far roughly counterbalanced by the construction of new dams [14,15].

At the regional scale, ocean dynamics and the inverse barometer effect modulate thermal expansion [4,16]. The mass contributions of mountain glaciers and ice sheets melting and groundwater extractions have regional patterns as well due to the response of the solid Earth to present-day mass redistributions [16-19]. Furthermore, the Earth is still responding to the past deglaciation (Global isostatic adjustment, GIA), so that, for example, regions in Scandinavia and Canada are still uplifting and other areas located in the periphery of past ice sheets such as the Chesapeake Bay in the United States are subsiding [20]. Finally, regional to local oceanic processes and vertical ground motions can alter regional relative water levels (with respect to the coast) and tides significantly [21-25]. State of 
the art global and regional sea-level projections available today consider all the processes above except the latter regional to local oceanic processes and vertical land motions [17-19,26-31].

Sea-level rise is a challenge for coastal adaptation, not only because it involves multidecadal and even multicentennial timescales, but also because it is associated with large uncertainties, even as soon as by the end of the 21st century [32]. Many previous studies have delivered probabilistic sea-level projections to convey these uncertainties to coastal adaptation practitioners [30]. Such projections usually assume a given climate scenario (e.g., RCP2.6 or $1.5^{\circ}$ of global warming) and deliver a probability distribution to describe their uncertainties. However, computing probabilistic projections requires making choices, including: selecting a subset of climate models [4]; choosing a particular ice-sheet modeling experiment (e.g., assuming Marine Ice Sheet Instabilities or Marine Ice Cliffs Instabilities [33,34]); introducing an expert judgement on the top of modelling outcomes to overcome limitation of models; or assuming dependencies among future contributions (e.g., quantifying the correlation between the melting of glaciers and ocean thermal expansion) [35]. These choices will result in different and potentially equally credible probabilistic sea-level projections [36]. Consequently, coastal adaptation practitioners may have difficulties to select those most appropriate to their needs [37-39].

In this paper, we deliver probabilistic sea-level projections by 2100 based on conservative assumptions (Available numerically as Supplementary Material). We call these "low-end probabilistic sea-level projections", because they are a credible—but extremely favorable-probabilistic representation of future sea-level rise. In other words, we call "low-end probabilistic sea-level projections" those delivering higher probability of exceedance than most credible probabilistic projections available in the literature. High-end sea-level scenarios and projections have received a lot of attention so far, because they are associated with high impacts and adaptation needs [40]. Nonetheless, low-end projections are equally useful for practitioners applying robust decision making or assessing minimum adaptation needs.

To produce probabilistic projections relevant for low-end sea-level changes, we select the smallest published probabilistic projections of mountain glaciers [41], of ice-sheet melting in Greenland [10] and in Antarctica [7]. Furthermore, we select a subset of models from the Coupled Model Intercomparison Project phase 5 (CMIP5) delivering moderate thermal expansion (Section 2). We use state-of-the art approaches to compute global and regional sea-level projections, relying only on modeling outcomes, without adding any expert judgement on the top of them, and selecting dependencies schemes among contributors that favor low sea-level change values up to the 50th percentile of the distribution [35] (Section 3). We deliver not only global, but also regional sea-level projections because they are the only one applicable at regional scales and therefore for adaptation (Section 4). Finally, we conclude by summarizing why our projections can be considered as low-end (Section 5).

\section{Data}

We use data from the Integrated Climate Data Center (ICDC) at the Hamburg University (http://icdc.cen.uni-hamburg.de/daten/ocean/ar5-slr.html) [27]. This dataset is based on CMIP5 climate models that were used in the regional sea-level projections of the 5th assessment report (AR5) of the Intergovernmental Panel on Climate Change (IPCC). It provides $1^{\circ} \times 1^{\circ}$ resolution spatial maps of sea-level rise and its components based on various atmosphere and ocean general circulation models (AOGCMs) and RCP scenarios.

\subsection{Sterodynamic Sea-Level Changes}

According to the terminology proposed by Gregory et al. (2019) [42], sterodynamic sea-level changes refer to the sum of the global mean thermosteric sea-level rise (i.e., sea-level rise due to thermal expansion) and the ocean dynamics corrected from the inverse barometer effect from the atmosphere. In the IPCC assessment, 16 (for RCP2.6) to 21 (for RCP4.5 and 8.5) AOGCMs from the CMIP5 exercise were used to compute this contribution to future sea-level rise. The dataset of the Integrated Climate Data Center at the Hamburg University [27] provides the sterodynamic sea-level 
changes for different AOGCMs and RCP scenarios (see Figure 1 and Appendix A). Here, we exclude two models (MIROC-ESM and MIROC-ESM-Chem), which are found to simulate anomalously large sterodynamic sea-level rise outside the Mediterranean sea of approximately $50 \mathrm{~cm}(2100, \mathrm{RCP} 8.5)$. This exceeds the median global-mean thermosteric sea-level rise of all other models $(30 \mathrm{~cm})$ beyond 5 sigma (i.e., a deviation larger by far from the standard criterion for outlier identification [43]). Without discarding the two MIROC-ESM models, the RCP8.5 global-mean thermosteric sea-level rise across models in 2100 is not distributed normally (see Section 3). Furthermore, to ensure consistency across RCP scenarios, we select the 14 climate models for which data are available in each climate scenario RCP2.6, 4.5, and 8.5 (see Figure 1 and Appendix A for individual model responses and ensemble means and standard deviations). The resulting mean and standard deviations are shown in the two bottom right panels of Figure 1 and Appendix A. As in previous studies, the mean and standard deviations display a regional maximum in the central North-Atlantic, close to the eastern coast of the United States and Canada. This "hot-spot" has been suggested to be caused by change in the Gulf Stream [44], but the uncertainties in projections of these changes remain very large in climate models [4], as emphasized by the large model spread (i.e., standard deviation) in this sector in Figure 1. In contrast, the model spread is smaller in tropical latitudes compared to mid- and high-latitudes.
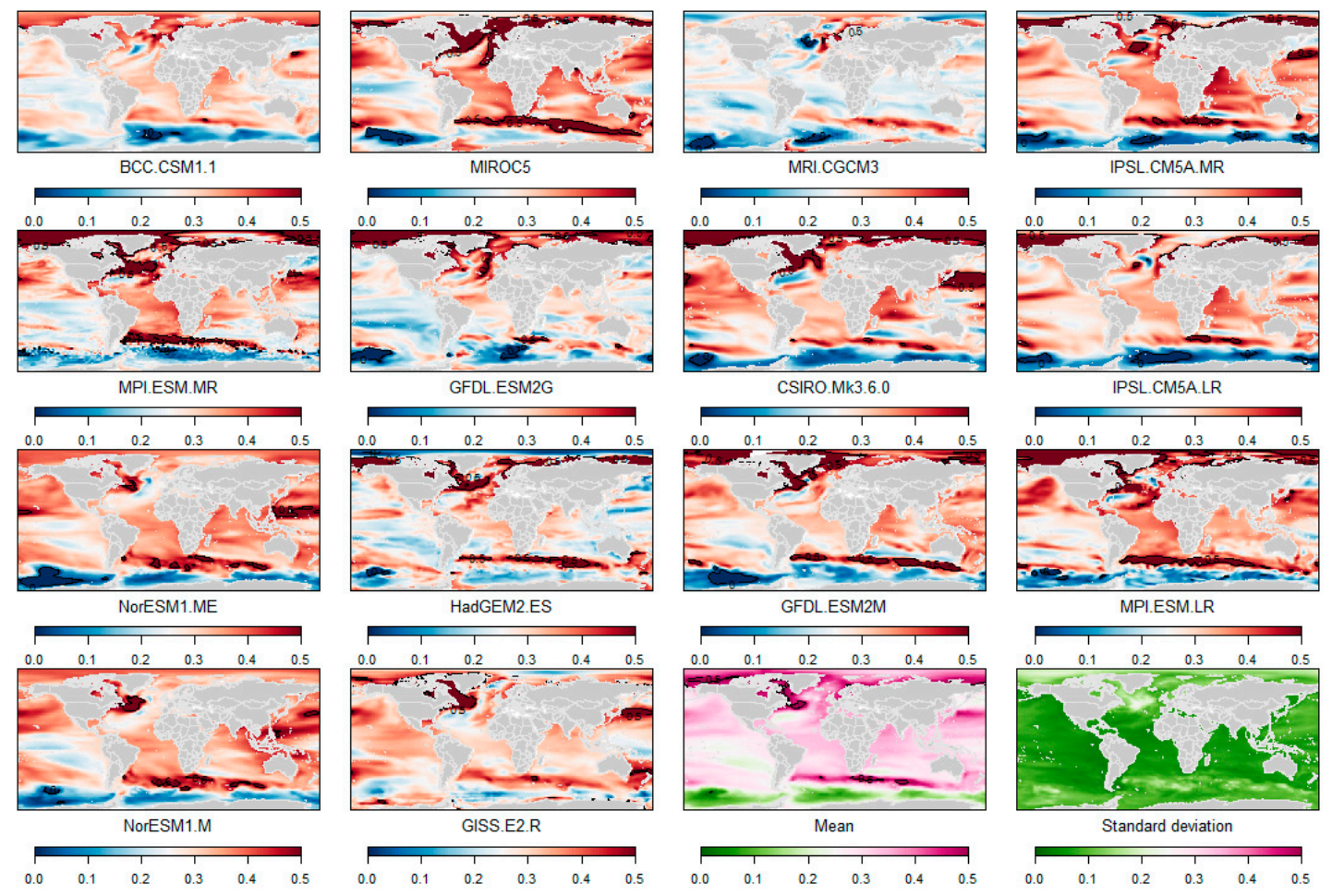

Figure 1. Sterodynamic sea-level changes (in m, for 2099 with respect to 1986-2005) for each climate model used in this study, their mean and standard deviation, for RCP8.5 and 2100. See Appendix A for RCP2.6 and RCP4.5.

Climate models used to compute future sterodynamic sea-level rise changes do not spatially cover the exact same ocean areas. In particular, discrepancies in model spatial coverage are obvious near coastal area and for semi-enclosed seas, e.g., among the 21 models used for the AR5, only 14 and 12 of them cover the Baltic and Mediterranean basins, respectively. If not accounted for, these spatial coverage differences can introduce discrepancies and biases when computing multimodel statistics, which in turn could significantly alter the credibility of coastal sea-level rise projections. To circumvent the intermodel spatial coverage difference issue, multimodel mean is calculated only for grid cells that are resolved by all models and the remaining empty grid cells are subsequently filled by interpolating from the nearest adjacent neighbors. Finally, we use the sea-level projections by 2099 and assume they 
hold for 2100 because some AOGCMs are missing in 2100. The impact of this approximation on our results is lower than $1 \mathrm{~cm}$.

In Table 1, we compare the global mean of sterodynamic sea-level changes used here with those presented in previous studies. Note that for some models (e.g., MIROC), the global mean of sterodynamic sea-level changes is not exactly equal to the thermosteric sea-level changes because some regions such as the Mediterranean are masked in the ICDC dataset. Marked discrepancies are found among studies listed in Table 1, because they use different subsets of models, and because some of them superimpose an expert judgment on the top of modelling outcomes. For example, the AR5 and several other studies $[19,29]$ interpreted "the 5 to $95 \%$ range of model results as the likely range" or one standard deviation of a t-distribution, which means that the standard deviation of model outcomes is multiplied by 1.64 in these studies. This reflects the IPCC AR5 WG1 Ch12 statement that "global mean surface air temperature change is likely to lie within the 5 to $95 \%$ range of the projections of CMIP5 models" [1]. This scaling factor is not applied in this study (see Section 3). We note that by removing models and by ignoring this latter procedure (multiplication of sigma by 1.64), we obtain slightly lower mean and standard deviation than previous studies. In particular, our selection of models removes outliers that deliver high sterodynamic sea-level changes.

Table 1. Comparison of the global mean of sterodynamic sea-level changes to sea-level rise by 2100. The global mean of sterodynamic sea-level changes is theoretically equal to the thermosteric contribution, but some numerical differences can be found (see text). The uncertainties below are those used as input for the global or regional sea-level change computations. Hence, they correspond to one standard deviation of AOGCMs outcomes in this study and in Jackson and Jevrejeva 2016 [45], but the 5-95\% range of AOGCMs outcomes in the AR5, in the Integrated Climate Data Center at the Hamburg University dataset and in Kopp et al. (2017) [46].

\begin{tabular}{cccc}
\hline Reference & RCP2.6 & RCP4.5 & RCP8.5 \\
\hline This study $^{1}$ & $0.14 \pm 0.03 \mathrm{~m}$ & $0.20 \pm 0.03 \mathrm{~m}$ & $0.30 \pm 0.03 \mathrm{~m}$ \\
IPCC AR5 (Global) [1] $^{1}$ & $0.15 \pm 0.05 \mathrm{~m}$ & $0.20 \pm 0.05 \mathrm{~m}$ & $0.32 \pm 0.07 \mathrm{~m}$ \\
Kopp et al. (2014) [19] $^{1}$ & $0.19 \pm 0.06 \mathrm{~m}$ & $0.26 \pm 0.08 \mathrm{~m}$ & $0.37 \pm 0.09 \mathrm{~m}$ \\
Integrated Climate Data Center at the $_{\text {Hamburg University }}{ }^{1}$ & $0.16 \pm 0.06 \mathrm{~m}$ & $0.21 \pm 0.07 \mathrm{~m}$ & $0.33 \pm 0.10 \mathrm{~m}$ \\
Jackson et Jevrejeva (2016) [45] $^{\text {Jack }}$ & N.A. & $0.21 \pm 0.05 \mathrm{~m}$ & $0.32 \pm 0.07 \mathrm{~m}$ \\
\hline
\end{tabular}

${ }^{1}$ In these studies, the standard deviation of model outcomes was multiplied by 1.64 .

\subsection{Mountain Glaciers}

Several studies have investigated future contributions of glaciers to sea-level rise $[9,47,48]$, but the projections of Huss and Hock (2015) [41] are 15-38\% smaller than previous estimates [31], except Hirabayashi et al. (2013) [49], who only provide estimates for the scenario RCP8.5. Huss and Hock (2015) [41] forced their global glacier evolution model with 14 AOGCMs from the CMIP5 dataset. They explain their lower projections of glacier melting by their modelling of glacier ice volumes located below sea levels that do not contribute to future sea-level change (one third of the difference with other studies), as well as by different calibration and modelling options such as the framework for glacier geometry change (two third of the difference with other studies). Their resulting values (mean \pm standard deviation) are $79 \pm 24 \mathrm{~mm}$ for RCP2.6, $108 \pm 28 \mathrm{~mm}$ for RCP4.5, and $157 \pm 31 \mathrm{~mm}$ for RCP8.5. These figures are relative to 2010, so that we add $12 \mathrm{~mm}$ based on observations of the glacier contribution to sea-level rise [50]. Huss and Hock (2015) [41] include the peripheral glaciers in Greenland and Antarctica, whereas they are not included in the ice-sheet mass budget in AR5 (see Table 2). 
Table 2. Global mean sea-level changes by 2100 relative to 1986-2005 assumed in this study (all Gaussian distributions). For comparison, the AR5 likely range and median contributions are provided for each component in italic and parenthesis, either in the form of "(median \pm half the likely range)", or "(median [likely range])" when the distributions are not centered. All values are rounded at two significant digits beyond the decimal point.

\begin{tabular}{|c|c|c|c|}
\hline Component & RCP2.6 & RCP4.5 & RCP8.5 \\
\hline Thermosteric & $\begin{array}{c}0.14 \pm 0.03 \mathrm{~m} \\
(0.15 \pm 0.05 \mathrm{~m})\end{array}$ & $\begin{array}{c}0.20 \pm 0.03 \mathrm{~m} \\
(0.20 \pm 0.05 \mathrm{~m})\end{array}$ & $\begin{array}{c}0.30 \pm 0.03 \mathrm{~m} \\
(0.32 \pm 0.07 \mathrm{~m})\end{array}$ \\
\hline Glaciers $^{1}$ & $\begin{array}{c}0.09 \pm 0.02 \mathrm{~m} \\
(0.11 \pm 0.06 \mathrm{~m})\end{array}$ & $\begin{array}{c}0.12 \pm 0.03 \mathrm{~m} \\
(0.13 \pm 0.06 \mathrm{~m})\end{array}$ & $\begin{array}{c}0.17 \pm 0.03 \mathrm{~m} \\
(0.18 \pm 0.08 \mathrm{~m})\end{array}$ \\
\hline Greenland ${ }^{1}$ & $\begin{array}{c}0.04 \pm 0.02 \mathrm{~m} \\
(0.08 \pm 0.04 \mathrm{~m})\end{array}$ & $\begin{array}{c}0.06 \pm 0.02 \mathrm{~m} \\
(0.09[0.05-0.16] \mathrm{m})\end{array}$ & $\begin{array}{c}0.10 \pm 0.03 \mathrm{~m} \\
(0.15[0.09-0.28] \mathrm{m})\end{array}$ \\
\hline Antarctica ${ }^{1}$ & $\begin{array}{l}0.02 \pm 0.04 \mathrm{~m} \\
(0.06 \pm 0.1 \mathrm{~m})\end{array}$ & $\begin{array}{l}0.04 \pm 0.04 \mathrm{~m} \\
(0.05 \pm 0.1 \mathrm{~m})\end{array}$ & $\begin{array}{c}0.09 \pm 0.06 \mathrm{~m} \\
(0.04[-0.08-0.14] \mathrm{m})\end{array}$ \\
\hline Groundwater $^{2}$ & $\begin{array}{c}0.05 \pm 0.08 \mathrm{~m} \\
0.05[-0.01-0.11] \mathrm{m}\end{array}$ & $\begin{array}{c}0.05 \pm 0.08 \mathrm{~m} \\
0.05[-0.01-0.11] \mathrm{m}\end{array}$ & $\begin{array}{c}0.05 \pm 0.08 \mathrm{~m} \\
0.05[-0.01-0.11] \mathrm{m}\end{array}$ \\
\hline
\end{tabular}

Global isostatic adjustment ${ }^{3} \quad$ Based on two different GIA models, as in AR5 [1]

${ }^{1}$ Including peripheral glaciers in Greenland and Antarctica for the projections of this paper, and excluding them for the IPCC figures. ${ }^{2}$ Because we use a Gaussian distribution, our standard deviation is not the same as half the AR5 likely range (see Section 2.5). ${ }^{3}$ Used for regional projections only.

\subsection{Greenland}

For Greenland, we rely on the study of Fürst et al. (2015) [10], which delivers global sea-level equivalent mass losses from the Greenland ice-sheet, in mm, relative to the 1986-2005 mean. This study forces an ice-sheet model accounting for surface mass balance effects and dynamic effects with ten AOGCMs from the CMIP5 dataset, considering the effects of vertical ground motions in Greenland. It shows that the dynamic ice melting of Greenland will be limited for large surface melting, because in this case, outlet glaciers currently located in the coastal margins and in contact with the ocean will retreat inland, therefore limiting dynamic effects due to ice in contact with the ocean. Therefore, the contribution of Greenland to sea-level rise is smaller in Fürst et al. (2015) [10] than for AR5 (e.g., for RCP8.5 and 2100: 0.07 to $0.13 \mathrm{~m}$ for Fürst et al. (2015) [10], vs. 0.09 to 0.28 for AR5), and, therefore, than the well-established probabilistic projections of Kopp et al. (2014) [19], who combined AR5 assumptions with the end-tail of the expert assessment of Bamber and Aspinall (2013) [51]. One study delivers slightly smaller Greenland contributions to future sea-level rise for RCP4.5 [52], but this may be due to ice-ocean interactions not being fully coupled in this study [52]. Furthermore, the results are not provided in a probabilistic form [52]. Finally, it is possible that even the projections of Fürst et al. (2015) [10] will be exceeded in the real world because all AOGCMs from the CMIP5 dataset underestimate mass losses observed in Greenland since the 1990s [53].

\subsection{Antarctica}

For Antarctica, we rely on Bulthuis et al. (2019) [7], who provide a contribution of Antarctic ice-sheet surface mass balance and dynamic effects in 2100 relative to 2000, which is approximately the same as with respect to a reference in 1986-2005 [1,54,55]. This study forces the "fast Elementary Thermomechanical Ice Sheet" (f.ETISh) Antarctic ice-sheet model [56] with regional ocean and atmospheric simulations. The f.ETISh model implements the key thermodynamic and mechanic properties of the Antarctic ice-sheet dynamics, including the accumulation of snow, the melting and calving of marine ice-sheets, and their interactions with ice-flow and bedrock motions. Despite its relatively coarse resolution of $20 \mathrm{~km}$, the f.ETISh model reproduces the marine ice-sheet instability (MISI) in West-Antarctica. f.ETISh does not consider the marine ice-cliffs instability (MICI), that is, a potential collapse of coastal ice cliffs triggered by ocean warming, surface melting, and hydro-fracturing [33,34]. 
MICI is not observed yet in Antarctica and it is associated with the largest potential contributions of Antarctica to sea-level rise. Hence, while it would be relevant to consider for high-end scenarios, $\mathrm{MICI}$ can be left out here as we focus on low-end sea-level projections.

The projections of Bulthuis et al. (2019) [7] are comparable to those of some previous studies [57], with the advantage of being delivered in a probabilistic format. They are even smaller than several previous studies disregarding the MICI [6,58] (see also Edwards et al. (2019) [34] and references therein). Bulthuis et al. (2015) [7] attribute their smaller projections to a relatively weak ocean forcing among other parametrization and initialization choices (see their Section 4). This self-assessment, the comparison with other modelling results and the fact that MICI is not considered implies that the projections of Bulthuis et al. (2019) [7] can be considered as low-end contributions of the Antarctica ice-sheet.

\subsection{Land Water}

For land water, we rely on the same studies than those assumed in AR5 [1], which assumed contributions of sea-level rise in 2100 of $0.04 \pm 0.05$ m relative to the 1986-2005 mean, whatever the RCP scenario. These projections take into account: groundwater net contributions to sea-level [15] and a negative contribution due to increased land water storage due to dams over the 21st century [59]. Here, we rely on the same lines of evidences as in AR5 but we reconsider the assumption previously done that the land water component of future sea-level rise follows a uniform distribution [1] because the two scenarios used in AR5 are not necessarily minimum and maximum bounds of this future contribution. We interpret these two scenarios as two plausible options, and use a Gaussian distribution with the same mean and variance based on the maximum entropy principle $[60,61]$.

\subsection{Summary of Inputs}

Table 2 summarizes our projected contributions to future sea-level rise in comparison with those used in AR5 [1]. As discussed above, the AR5 figures and ours differ for the following reasons: first, the number of models used to compute the projections is not the same; secondly, the peripheral glaciers in Antarctica are included in the Antarctic contribution in AR5, whereas it is included in the Glacier contribution in our results; third, the IPCC considers "the 5 to $95 \%$ range of model results for each of the global mean sea-level rise contributions that is projected on the basis of CMIP5 results ( . . ) as the likely range.", whereas we directly rely on the mean and standard deviation of model outcomes and do not expand the spread of uncertainties in subsequent procedures (see Section 3 for justification of this choice). In many cases, Table 2 shows that our choices lead to selecting smaller contributions to future sea-level rise than in AR5, and the subsections above justify that for the other cases (thermosteric, glaciers and groundwater), our assumptions can still be considered as low-end.

\section{Methods}

\subsection{Integration: From Sea-Level Contributions to Global and Regional Sea-Level Scenarios}

We compute global and regional sea-level rise projections by summing their components globally and regionally as in previous studies $[1,17-19,26,29,46]$. Global projections of mean sea-level rise are obtained by summing the global mean thermosteric and barystatic sea-level changes (Figure 2), whereas regional projections of sea-level rise consider the changes in ocean dynamics and circulation, as well as the "Earth Gravity, Earth Rotation (and hence centrifugal acceleration) and viscoelastic solid-Earth Deformation (GRD)", which includes contemporary GRD changes due to ongoing redistributions of water masses and the visco-elastic response to past deglaciation, that is, the Global Isostatic Adjustment (GIA) [42]. Note that the regional sea-level projections produced here are not necessarily equal to projected relative sea-level changes as per the terminology of Gregory et al. (2019) [42], because they do not include local vertical ground motions. Where they are known, these local vertical ground motions should be added to (subsidence) or removed from (uplift) our sea-level projections [25]. 
In practice, we compute the contemporary GRD changes using the same fingerprints as AR5, assuming that the contribution of Greenland originates from the whole ice-sheet, and that the contribution of Antarctica originates from the "western" part of the ice-sheet. These assumptions lead to errors, for example, in Patagonia and in the Arctic [62]. However, far from the ice-sheets, these errors are acceptable given the uncertainties of each contribution to sea-level rise. We also compute the global thermosteric contribution by averaging sterodynamic sea-level changes globally. Both quantities are theoretically equal, but there are small numerical differences (see Section 2), which are negligible compared to projected sea-level changes and uncertainties. More details on the methods to compute sea-level projections based on their components can be found in Slangen et al. (2012), Kopp et al. (2014), and the IPCC AR5 [1,17,19].

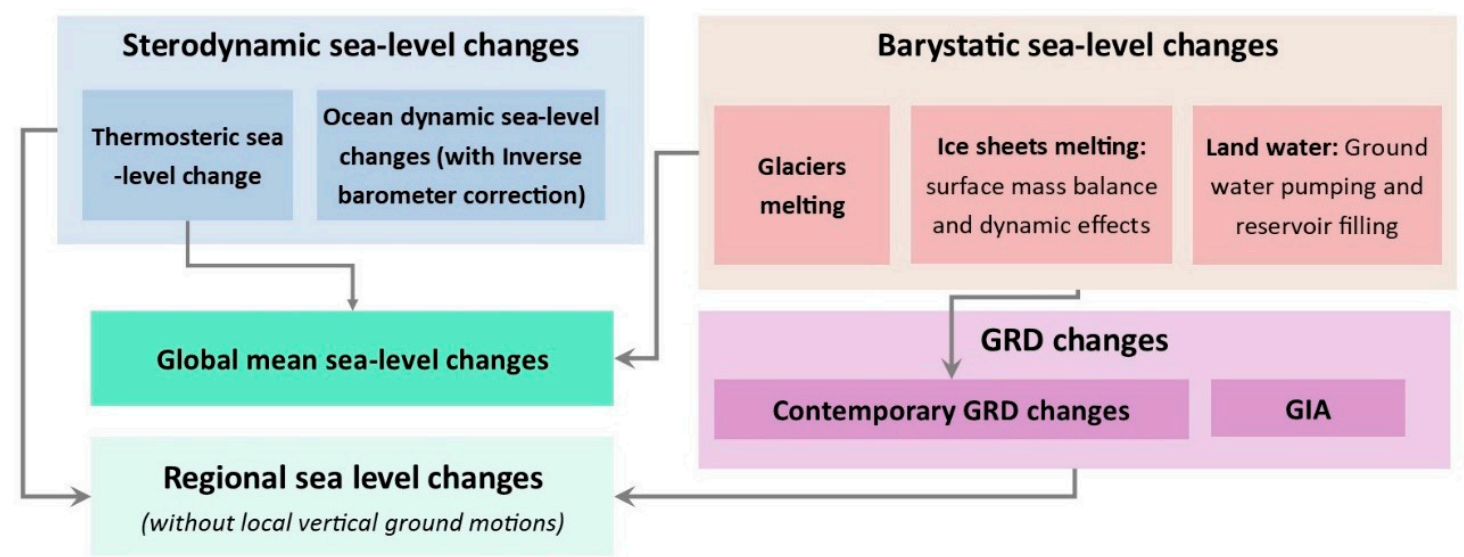

Figure 2. Method to compute global and regional sea-level changes (see Gregory et al., 2019 [42] for the terminology).

\subsection{Probabilistic Distributions for Individual Components to Sea-Level Rise}

In AR5 and other studies, "the 5 to $95 \%$ range of model results for each of the global mean sea-level rise contributions that is projected on the basis of CMIP5 results is interpreted as the likely range" [1]. Here, we use the mean and standard deviation of models outcome directly as input to compute global and regional sea-level projections, and we do not apply this scaling factor in this study, based on the following arguments: first, climate models have essentially delivered conservative sea-level rise projections so far [53,63-65]; second, preliminary CMIP6 experiment outcomes display higher climate sensitivity than CMIP5, so that the ocean heat uptake of these modeling results would be equal or larger than in CMIP5 simulations, and Greenland and Mountain glacier ice masses would be affected similarly. Hence, we recognize that it is legitimate to enlarge the variance of sea-level contributions in order to capture the possibility to exceed the model's outcomes (i.e., the upper tail of probabilistic sea-level projections), but in the perspective of exploring low-end scenarios, we could not find any argument in the published literature supporting the hypothesis that future sea-level rise could finally end up below models outcomes.

There is an uncertainty associated with the assumption that model outcomes are normally distributed. This uncertainty can be evaluated using a bootstrap approach, in which we select all possible subsets of models to compute the normal distributions that would come out if less models were available. Figure 3 shows that when globally averaged, the subset of models used for the thermosteric component (Figure 3, right) better fit Gaussian distribution than the original selection of models used in AR5 (Figure 3, left, note in particular the reduction in the width of the error envelop). In fact, among the 21 CMIP5 models, MIROC-ESM and MIROC-ESM-Chem models clearly appear as outliers (Figure 3, top left panel, upper end of the cumulative distribution function). Note that if these two models are discarded, the distribution of global thermosteric sea-level rise obtained by the 19 remaining CMIP5 models is no longer significantly different from a Gaussian distribution according 
to the Shapiro-Wilk normality test. This conclusion is also supported by applying the Tietjen-Moore test [66], which indicates that the two most extreme points are outliers. Here, we further reduce the number of AOGCMs to 14 in order to have a consistent approach across RCP scenarios. A more complete analysis of the Gaussian assumption was conducted by Jackson and Jevrejeva (2016) [45] for each $1^{\circ} \times 1^{\circ}$ cell of the sterodynamic sea-level rise projections maps, concluding that the sterodynamic component of individual models was normally distributed once a few outliers were removed.
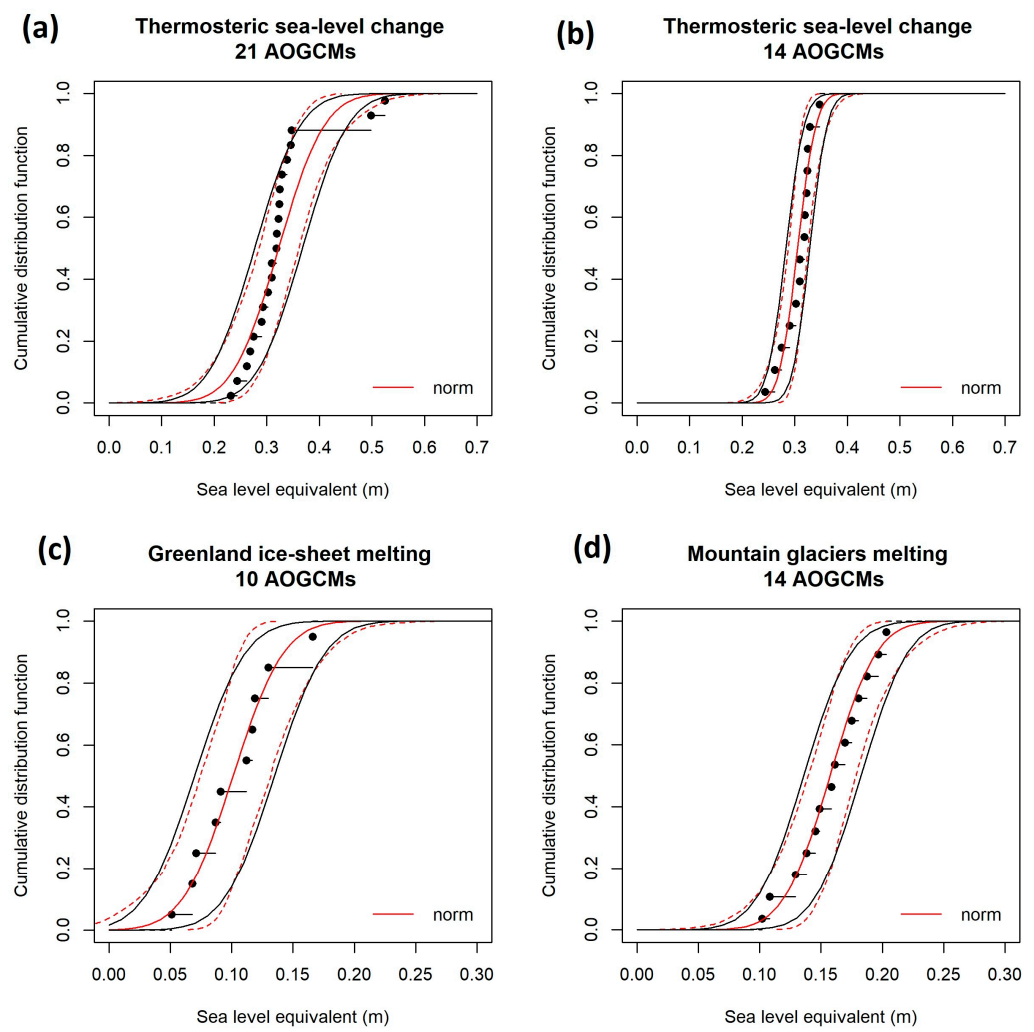

Figure 3. Bootstrap analysis (using 1000 random replicates) of the Gaussian assumption of contributions to sea-level rise in 2099 for RCP8.5. (a): 21 models used in AR5 (regional results); (b): subset of models used in this study; (c): Greenland [10]; (d): Mountain glaciers [41]. Black dots correspond to the empirical cumulative distribution function and the solid red curve is its Gaussian fit. Dashed red curves indicate maximum and minimum empirical cumulative distributions delivered by the bootstrap procedure. Solid black curves indicate the maximum and minimum Gaussian fits. This figure allows estimating the potential error made with Gaussian assumptions in this study.

Figure 3 (Bottom panels, (c) and (d)) also shows that for Greenland and Mountain Glaciers, the model outcomes are approximately normally distributed. Based on Figure 3 and the previous investigations of Jackson and Jevrejeva (2016) [45] and Bulthuis et al. (2019) [7], we rely on Gaussian distributions for the individual components to future sea-level rise, but we recommend not using the resulting projections beyond the 5th-95th percentiles due to the limited number of models constraining input distributions. In fact, the sample size to estimate the 95th percentile at a confidence of $95 \%$ is 59 following Wilk's formula [67], suggesting that even these 5th and 95th percentiles should be considered with caution.

\subsection{Computational Approach and Statistical Dependencies}

The probabilistic projections presented in this paper are computed by summing the relevant global and regional component of future sea-level rise (Section 3.1) using a Monte-Carlo approach. The propagation is conducted by sampling uniform random variables (termed as auxiliary variables) 
between 0 and 1 and by using the inverse cumulative distribution functions of the corresponding components. In the independent case, six auxiliary variables (one for each of the six components) are randomly and independently sampled. In the fully dependent case, a unique auxiliary variable is used for the thermosteric (or sterodynamic at regional scale), Mountain Glaciers and Greenland components. We use the R HYRISK package (Hybrid Methods for Adressing Uncertainty in Risk Assessments) [68] supplemented by functions allowing to perform quasi-random simulations (Sobol' sequence of quasirandom numbers, see Bratley and Fox (1988) [69]) that accelerate the convergence of Monte-Carlo simulations. We perform 4000 quasirandom simulations, which allows obtaining smoothed regional and global sea-level projections.

Several future contributions of sea-level rise depend on the mean surface atmospheric temperature [1]. This means that statistical dependencies should be modelled when running the Monte-Carlo procedure producing probabilities sea-level projections [35]. To explore the ambiguity in probabilistic projections due to unknown statistical dependencies between components, we consider two idealized cases (Table 3), following Le Bars et al. (2018) [35]: A first case where all contributors to future sea-level rise are uncorrelated ("Ind" case) and a second case assuming that ocean thermal expansion and Mountain Glaciers and Greenland melting are fully correlated due to their dependence on atmospheric temperature ("Dep" case). The uncertainties of sea-level projections will be smaller for the "Ind" case than in the "Dep" case, and partial correlation cases will fit between the two cumulative distributions. We do not explore the possibility that the future contribution of Antarctica is correlated with other contributions because the accumulation of snow over Antarctica is expected to increase as climate warming intensifies, and because the role of climate warming in the marine ice sheets instabilities is not established yet [1]. These two cases ("Ind" and "Dep") allow to bound the probability distributions under any realistic dependency scheme given the scientific evidences available today. For the regional projections, we select the "Dep" case because it delivers the most optimistic justifiable correlation scheme below the median. This is because we assume that users of low-end sea-level projections have a low aversion to uncertainty, and will therefore consistently refer to the median scenario, or even the 5 th or 17 th percentiles.

Table 3. Dependencies schemes used in this paper.

\begin{tabular}{ccc}
\hline Correlation Scheme Name & Global Experiments & Regional Experiments \\
\hline "Ind" & All components uncorrelated & All components uncorrelated \\
\hline "Dep" & $\begin{array}{c}\text { Fully correlated Thermosteric, Mountain } \\
\text { Glaciers and Greenland components }\end{array}$ & $\begin{array}{c}\text { Fully correlated Sterodynamic, Mountain } \\
\text { Glaciers and Greenland components }\end{array}$ \\
\hline
\end{tabular}

\section{Results}

\subsection{Global Probabilistic Sea-Level Projections}

Figure 4 displays the cumulative distribution functions of the global sea-level rise probabilistic projections, and Table 4 provides the percentiles in the "Dep" case, for three RCP scenarios. The 5th percentiles are extremely low for RCP2.6 and 4.5 and imply a deceleration of sea-level rise over the 21st century. Indeed, sea-level rise might not exceed $17 \mathrm{~cm}$ in 2100 (5th percentile of the RCP2.6 scenario) if, as soon as 2020, sea level rise turns back to the 20th century rates estimated by Hay et al. (2015) [70] and Dangendorf et al. (2017) [71]. If this low-end scenario occurs, the accelerated sea level rise observed since 1993, which is now largely attributed to Greenland melting [55,72], will appear retrospectively as a multidecadal mode of climate variability, and the thermal expansion and/or the contribution of Glaciers should be dampened as well. Such a scenario is obviously extremely optimistic and illustrates that values below the 5 th percentile are not credible. In contrast, there are good reasons to believe that the 95th percentile of our projections can be exceeded because we systematically selected the smallest probabilistic projections available for all climate-related contributors to sea-level rise (see Section 2). 
As revealed by the comparison between the "Ind" and "Dep" cases of each RCP scenario, the effect of the two different dependency schemes is in the order of a few centimeters from the 5th to the 95th percentiles, which is small and probably insignificant for many stakeholders. This is not inconsistent with Le Bars (2018) [35], who found that different dependency schemes account for differences in sea-level projections in the order of $20 \mathrm{~cm}$ for the 95th percentile. In fact, he considered a fully dependent scheme, which we do not consider here (see Section 3 for justification of our dependency schemes). We note that the 5th percentile of RCP8.5 projections $(46 \mathrm{~cm})$ imply a slight acceleration of sea-level rise. This implies that even in an extremely optimistic case, an acceleration of sea-level rise cannot be avoided for a business as usual greenhouse gas emission scenario (RCP8.5).

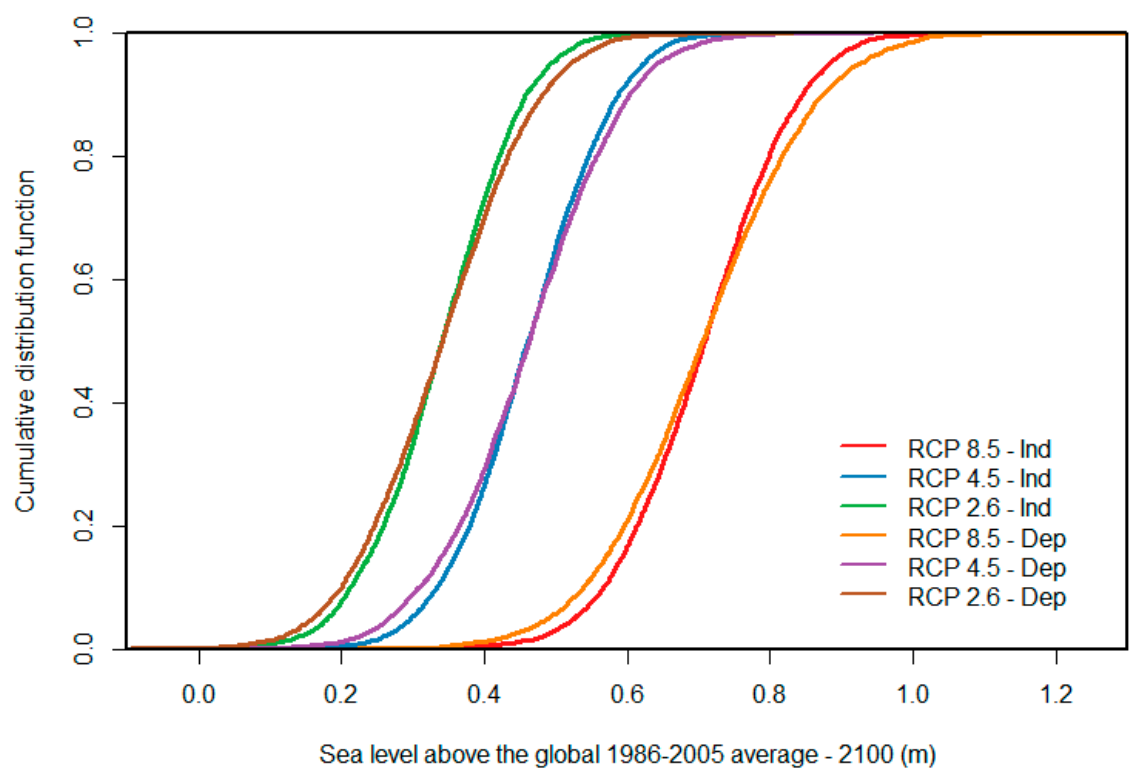

Figure 4. Global probabilistic sea-level projections obtained in this study (2100, with respect to a 1986-2005 average; unit: m).

Table 4. Global mean sea-level rise projections by 2100 relative to $1986-2005$ (“Dep” case).

\begin{tabular}{cccccc}
\hline RCP Scenario & $\mathbf{5 \%}$ & $\mathbf{1 7 \%}$ & $\mathbf{5 0} \%$ & $\mathbf{8 3} \%$ & $\mathbf{9 5 \%}$ \\
\hline RCP2.6 & $0.17 \mathrm{~m}$ & $0.23 \mathrm{~m}$ & $0.34 \mathrm{~m}$ & $0.45 \mathrm{~m}$ & $0.52 \mathrm{~m}$ \\
RCP4.5 & $0.27 \mathrm{~m}$ & $0.35 \mathrm{~m}$ & $0.46 \mathrm{~m}$ & $0.57 \mathrm{~m}$ & $0.63 \mathrm{~m}$ \\
RCP8.5 & $0.48 \mathrm{~m}$ & $0.58 \mathrm{~m}$ & $0.70 \mathrm{~m}$ & $0.83 \mathrm{~m}$ & $0.92 \mathrm{~m}$ \\
\hline
\end{tabular}

In Figure 5, we compare our low-end probabilistic sea-level projections to other projections available in the literature in the case of the RCP8.5, which is associated with further massive exploitation of fossil fuel [73]. Garner et al. (2018) [30] provide a more complete review of all existing sea-level projections, showing that the projections of Jackson and Jevrejeva (2016) [45] belong to the smallest if their high-end is discarded. As expected, our results are smaller than those of many recent studies: only the values of Jackson and Jevrejeva (2016) [45] and those of AR5 are smaller up to the 30th percentile. This is because our input contributions have lower uncertainties than these studies (see, e.g., Table 1 in Jackson and Jevrejeva (2016) [45]), which is itself due to our selection of models and studies (see Section 2), and due to us not multiplying the uncertainty of projections by 1.64 (see Section 3.2 and Church et al. (2013) [1]). These modeling choices are perfectly justified in the previous studies and assessments, but they were essentially introduced to deliver more realistic upper tails of probabilistic sea-level projections. Here, we note that these choices also affect the lower tail of probabilistic sea-level projections in a way that affects their credibility. In fact, only previous studies based on AR4 and CMIP3 results delivered even lower projections (e.g., Perrette et al. (2013) [74]: see their low case AR4+), but the improvements in ice-sheet melting processes and Mountain Glaciers inventories done 
since AR4 prevent from considering AR4 projections at present. As a consequence, there is presently no CMIP5 modeling outcome of other line of evidence supporting the probabilistic projections derived from IPCC (2013) below the 20th quantile.

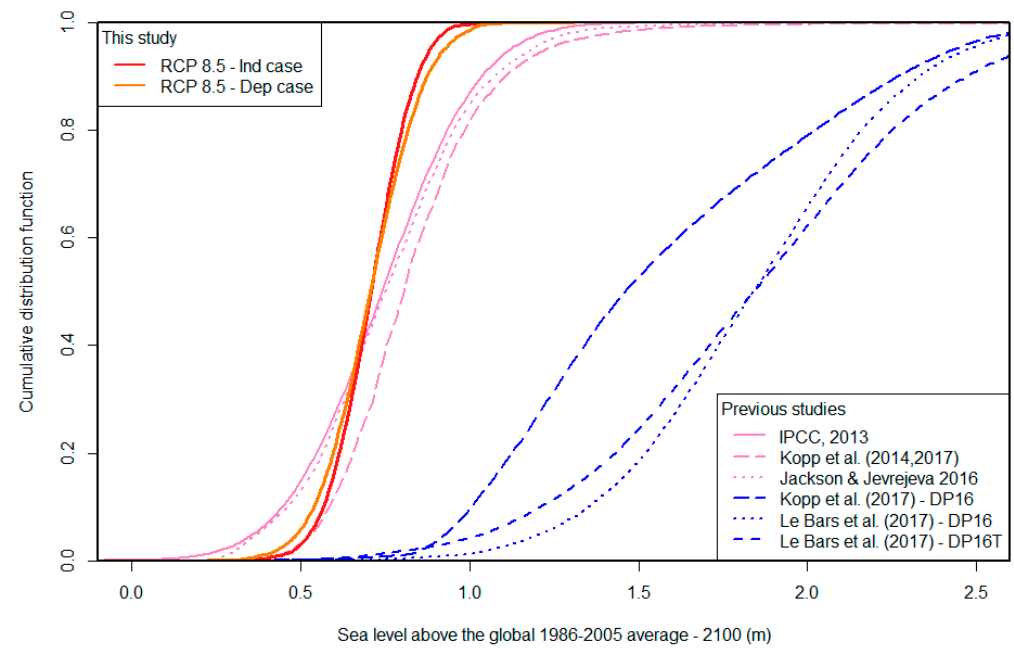

Figure 5. Comparison of global probabilistic projections with previous studies $[1,19,29,35,45,46]$, RCP8.5, 2100 (unit: m); DP16 refers to De Conto and Pollard (2016) [33].

\subsection{Regional Sea-Level Projections}

Figure 6 displays the regional sea-level projections (median, 17th, and 83rd percentiles). Appendix $B$ displays the 95th and 5th percentiles for RCP2.6, 4.5, and 8.5. For RCP2.6, we project a low-end median sea-level rise not exceeding $0.5 \mathrm{~m}$ in 2100 along most inhabited coastlines (local vertical ground motions not included). However, the RCP2.6 scenario would be associated with ambitious climate change mitigation policies, which are not implemented yet [75]. For the RCP4.5 scenario, which is achievable if countries apply their current intended nationally determined contributions [76], the threshold of $0.5 \mathrm{~m}$ would be exceeded along the coasts of north-eastern America, as well as in the Southern Atlantic and Indian ocean, thus potentially affecting vulnerable African countries and islands [77]. However, only 17 countries among 197 have demonstrated that they have taken sufficient measures to reach own intended nationally determined contributions [78]. For RCP8.5, which corresponds to business as usual [73], our low-end median sea-level projection always exceeds $0.5 \mathrm{~m}$ along most inhabited coasts. We argue that coastal adaptation practitioners should consider the RCP8.5 scenario because the mitigation policies that would allow preventing it are not implemented yet [78].

These results have practical implications for adaptation: some countries and agencies are including sea-level scenarios in their regulations or design guidance as part of their adaptation policies $[37,38,40]$. In France, for example, a $0.6 \mathrm{~m}$ sea-level rise scenario in 2100 is included in coastal risk prevention plans to limit urbanization in low-lying areas [38]. Our results show that with sustained greenhouse gas emissions and in the optimistic case considered here, there is still approximately one chance in two to exceed the regulatory scenario (Figure 5). Ways forward to deal with this issue include communicating on the low security margin associated with the current regulation, increasing the regulatory scenario, shortening time horizons decisions (e.g., 2050 instead of 2100), or doing nothing, for example, if adaptation practitioners consider that the current regulation delivers substantial advantages already.

The knowledge of the low-end sea-level projection is crucial for a proper estimation of extremes, and the associated coastal flood and erosion hazard. It is crucial not only by itself, but also because sea-level rise has a significant effect on tides, surge, waves, nearshore bathymetry, and shoreline evolution in many places around the world. For example, for a typical sea-level rise of $1 \mathrm{~m}$, tidal amplitude can exhibit changes (positive or negative) of few centimeters to tens of centimeters, while the tide itself can 
locally modify the surge by several tens centimeters [79]. Focusing for instance on the North Western European shelf, tide changes are proportional to the sea-level rise, at least as long as sea-level rise does not exceed $2 \mathrm{~m}$, such that smaller tide changes are expected from small sea-level rise [21]. But, in addition, as highlighted by Haigh et al. (submitted) [80], tide is changing due to many other processes (harbor infrastructures, long-term changes in the tidal potential, changes in internal tide, morphological changes ...). While the effects of these processes on tide changes can be considered negligible in the context of high-end sea-level rise projections associated to large uncertainties, they could be relevant for precise assessments in the context of low-end mean sea-level projection. Hence, the precise estimation of low-end extreme water levels at the coast would not only require evaluating the variability and changes in waves, surges $[22,23,81,82]$, but also account for changing local tides, or at least, better account for the related uncertainties.

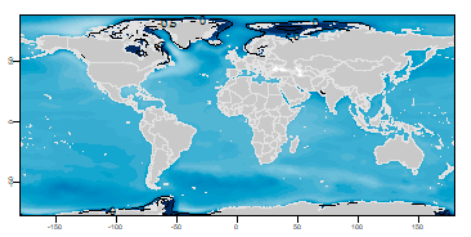

RCP 2.6 - 17th percentile

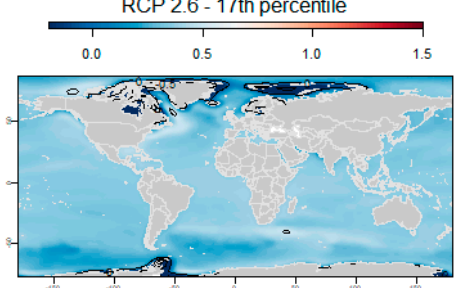

RCP 4.5 - 17 th percentile
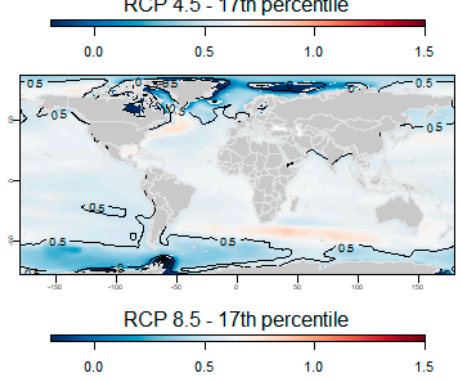

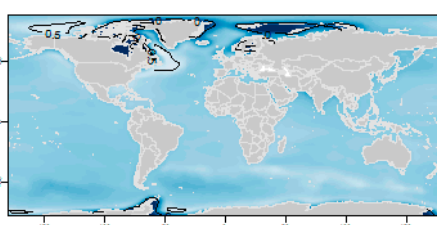

RCP 2.6 - Median

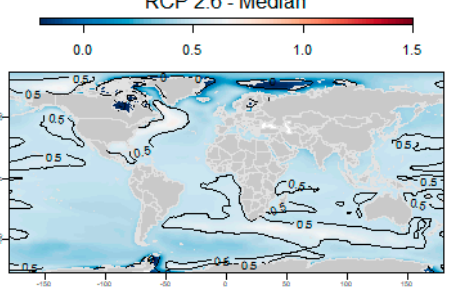

RCP 4.5 - Median

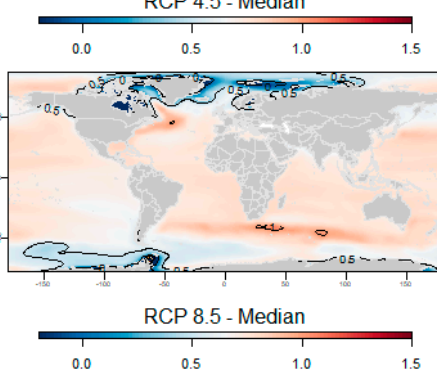

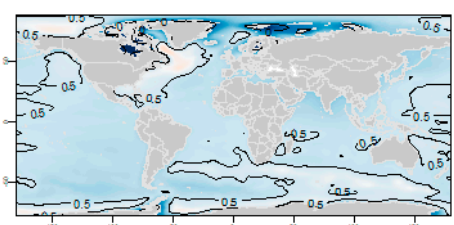

RCP 2.6 - 83rd percentile

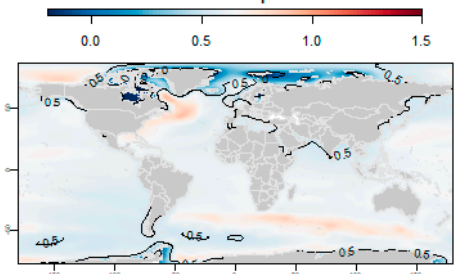

RCP 4.5 - 83rd percentile

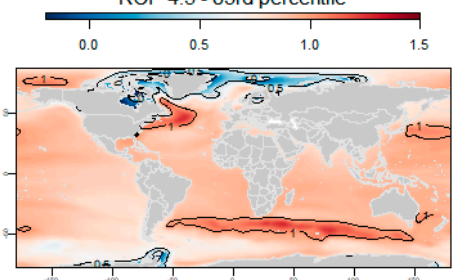

RCP 8.5 - 83rd percentile

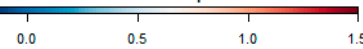

Figure 6. Regional low-end sea-level scenarios in 2100 for the RCP2.6, 4.5, and 8.5 scenarios (unit: m).

\section{Discussion and Conclusions}

In this paper, we provide global and regional low-end probabilistic sea-level projections (available as Supplementary Material). Our projections are probabilistic because they are generated from probabilistic representations of all components of future sea-level rise, mostly obtained by fitting Gaussian distributions to global and regional modeling outcomes. They are low-end projections because they represent sea-level rise and its uncertainties under very optimistic sterodynamic and barystatic sea-level changes. Specifically, our probabilistic sea-level projections are very optimistic because:

(1) We used recent studies delivering the smallest probabilistic contributions from Mountain Glaciers, Greenland, and Antarctica [7,10,41];

(2) For Antarctica, we relied on a study that probably underestimated the impact of ocean warming on the Antarctic marine ice-sheet melting, according to its own assessment [7];

(3) For the sterodynamic sea-level changes, we removed AOGCMs giving high thermal expansion values; in the regional AR5 assessment, these outliers increased the mean and uncertainties of the thermal expansion. 
(4) We relied on modelling outcomes only, and ignored the procedure consisting of multiplying the standard deviation of model outcomes by 1.64 applied in the AR5; we argue that this procedure artificially extends the lower tail of the distribution of future sea-level rise, whereas AOGCMs have been essentially criticized so far for minimizing future sea-level changes.

(5) We assumed full dependency among the sterodynamic, Mountain Glaciers, and Greenland melting components, which slightly shifts the lower tail of the probability distribution to the right compared to partial dependency schemes;

(6) We did not find physical arguments supporting probabilistic projections below our projections in the published literature.

Hence, our projections can be considered as a low-end probabilistic projection if not a probabilistic lower bound. The lower tails of some existing probabilistic sea-level projections are lower than ours, but these lower tails lack credibility, due to their being affected by modelling choices essentially made to deliver more realistic upper tails (see Section 4). If new processes are identified in the future, slightly more conservative low-end probabilistic projections might become credible. However, we speculate that the resulting distribution should not be that much different from ours, as otherwise, this would mean an inexplicable decrease of the rates of sea-level rise despite climate warming.

Even with these optimistic assumptions, our results show that an acceleration of sea-level rise should be expected during the 21st century under business as usual greenhouse gas emissions (RCP8.5), which was not guaranteed by all previous probabilistic sea-level rise projections (see Section 4.1). This result has significant implications for adaptation: for example, even under these optimistic projections, the regulatory sea-level scenario adopted in France has roughly one in two chance to be exceeded by 2100 under business as usual greenhouse gas emissions (RCP8.5). This result might be considered in future updates of such adaptation policy and engineering guidance, especially if the gap between climate mitigation targets and the real greenhouse gas emissions continues to grow.

There are physical arguments to argue that our projections are extremely conservative: for example, other trustful subsets of AOGCMs have delivered higher thermal expansion (e.g., in Kopp et al. (2014) [19]). Furthermore, our study relies on CMIP5 data, which will be soon superseded by CMIP6 with potentially higher climate sensitivity and therefore thermal expansion. As a consequence, they should only be used cautiously, keeping in mind that they have good chances to be exceeded in the real world, so that nuisances and losses due to flooding, erosion, and salinization will be significantly larger [83].

Supplementary Materials: The following are available online at http://www.mdpi.com/2073-4441/11/7/1507/s1: regional low-end probabilistic projections.

Author Contributions: Project design: G.L.C.; methods: G.L.C., R.T., J.R., J.-C.M.; software for uncertainty analysis: J.R., J.-C.M.; software for sea-level projections: R.T., R.Q., G.L.C.; analysis of the results: G.L.C., R.T., D.I., J.R.; writing: All.

Funding: This research was funded by BRGM and the ERA4CS (grant number: 690462): GLC and JR through the INSeaPTION project; RT, JCM, ID and RQ: ECLISEA project. This research also contributes to the ANR DELTA project (French National Research Agency, ANR-17-CE03-0001) and the Convention on financial support for climate services of the French Ministry for an Ecological and Solidary Transition (MTES).

Acknowledgments: We thank numerous colleagues for discussions that allowed performing this study, including: Catherine Ritz, Franck Pattyn, Angélique Melet, Mélanie Becker, Gael Durand, Robert Nicholls, Dewi Le Bars, Detlef Stammer, Erwin Lambert, David Salas-y-Mélia, Svetlana Jevrejeva and the participants to the WCRP Sea-Level Grand Challenge. We thank especially Aimée Slangen, Benoit Meyssignac and Mark Carson for sharing their data and expertise. We thank two reviewers for their insightful comments that improved our paper. We thank Anny Cazenave and William Llovel for inviting us to submit an original research work to this special issue.

Conflicts of Interest: The authors declare no conflict of interest.

\section{Appendix A. Sterodynamic Sea-Level Changes (2099, with Respect to 1986-2005)}

Figures A1 and A2 below display the outcome of individual models used in this study for the sterodynamic component in 2100 for the RCP2.6 (Figure A1) and RCP4.5 (Figure A2) scenarios. 
The mean and standard deviation of these models are provided as well. They are displayed in more detail in Figure A3.
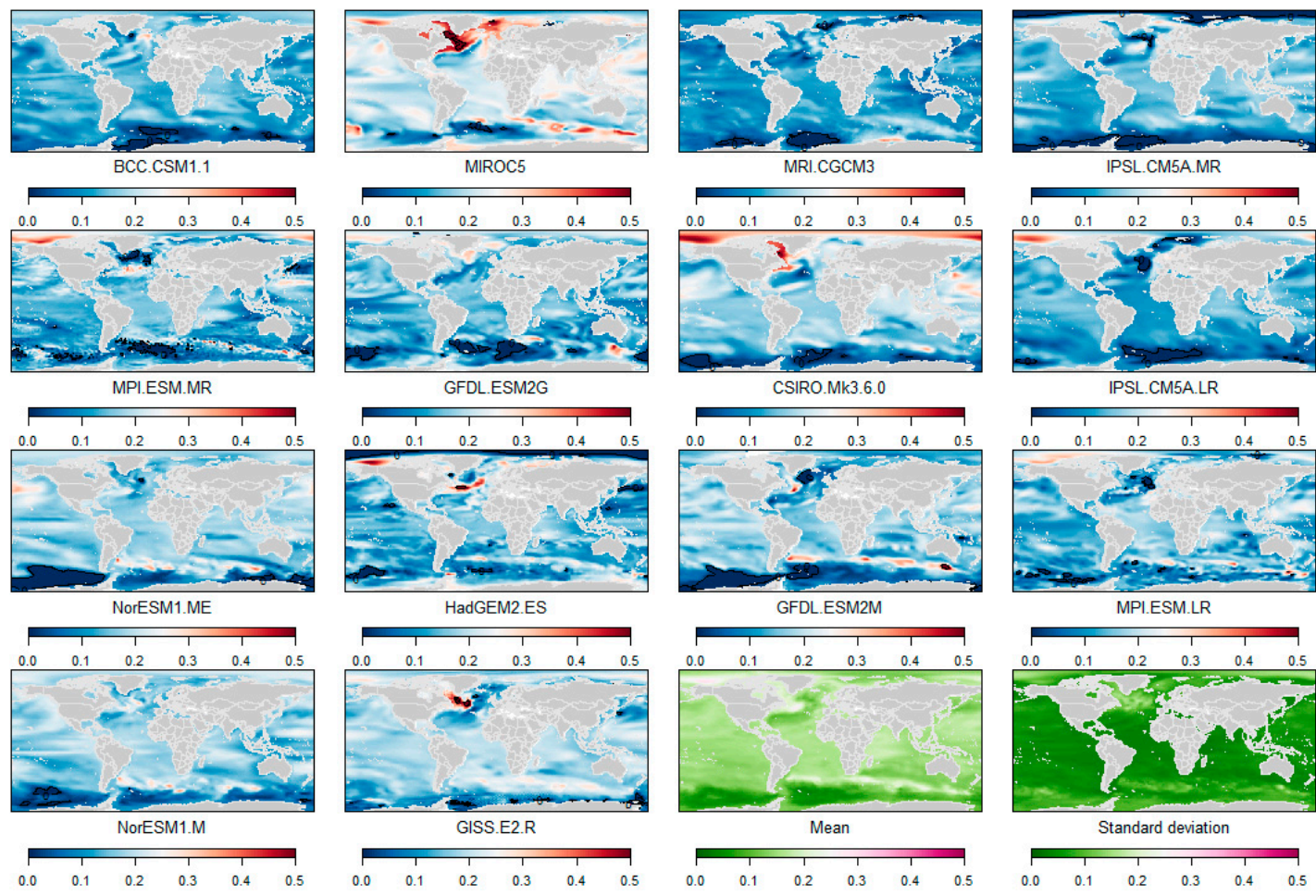

Figure A1. Sterodynamic sea-level changes (in m, for 2099 with respect to 1986-2005) for each climate model used in this study, their mean and standard deviation, for RCP2.6.
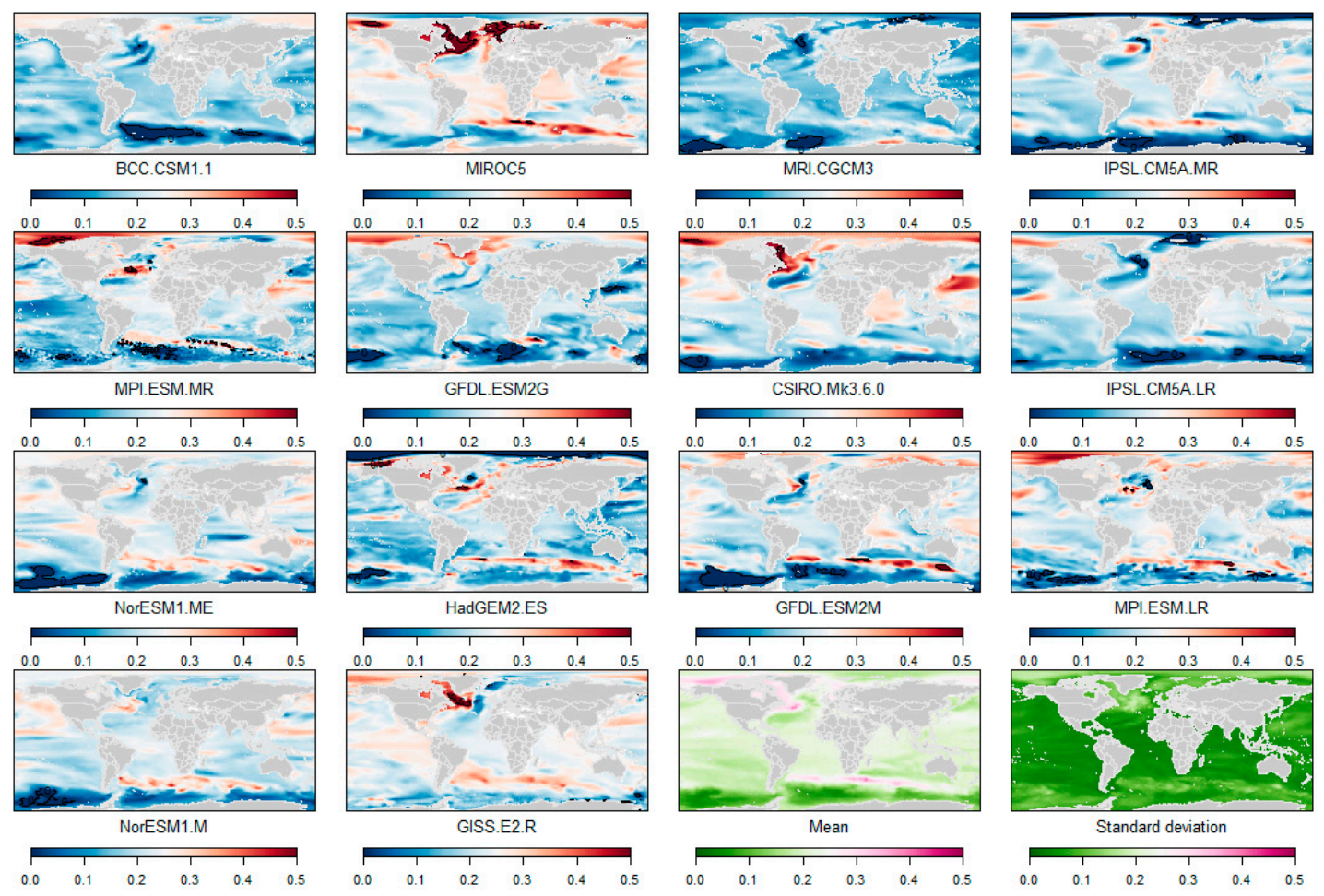

Figure A2. Sterodynamic sea-level changes (in m, for 2099 with respect to 1986-2005) for each climate model used in this study, their mean and standard deviation, for RCP4.5 and 2099. 


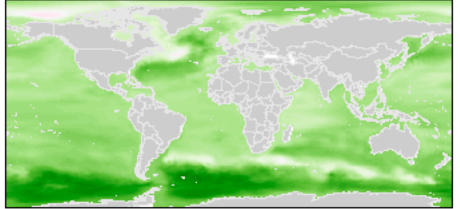

Mean - RCP 2.6
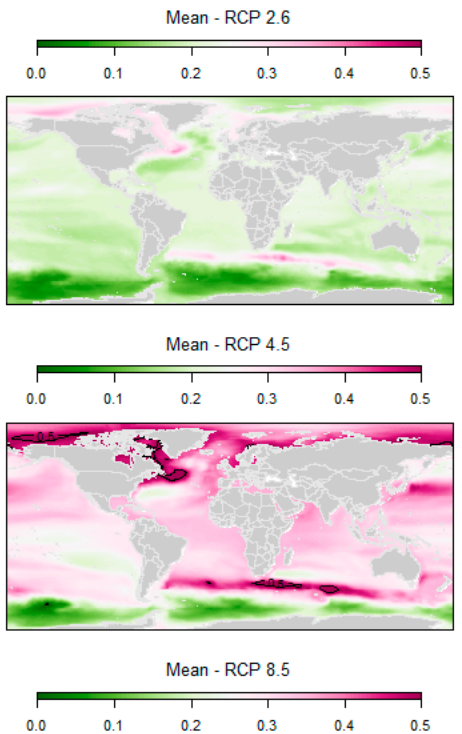

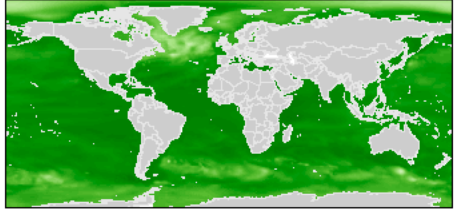

Standard deviation RCP 2

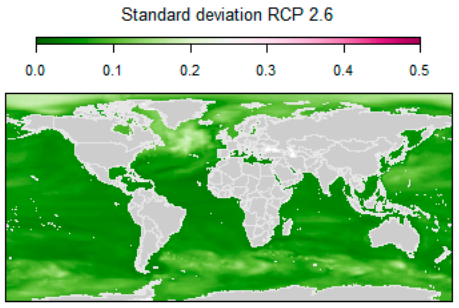

Standard deviation RCP 4.5

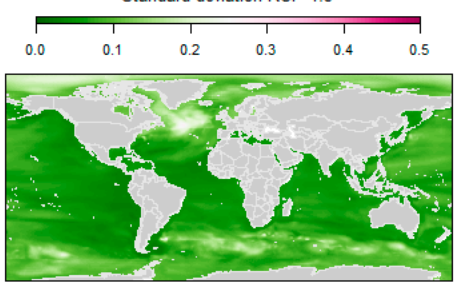

Standard deviation RCP 8.5

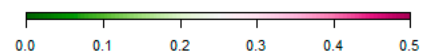

Figure A3. Mean and standard deviation of sterodynamic sea-level changes (in $\mathrm{m}$, for 2099 with respect to 1986-2005) for RCP2.6, RCP4.5 and RCP8.5 by 2099.

\section{Appendix B. Regional 5th and 95th Percentiles of the Regional Low-End Sea-Level Projections}

The Figure below displays the 5th and 95th percentiles of our low-end probabilistic projections. They should be considered with caution because the probabilistic inputs that have been used to generate this dataset is based on up to 14 model outcomes (See Section 3.2).
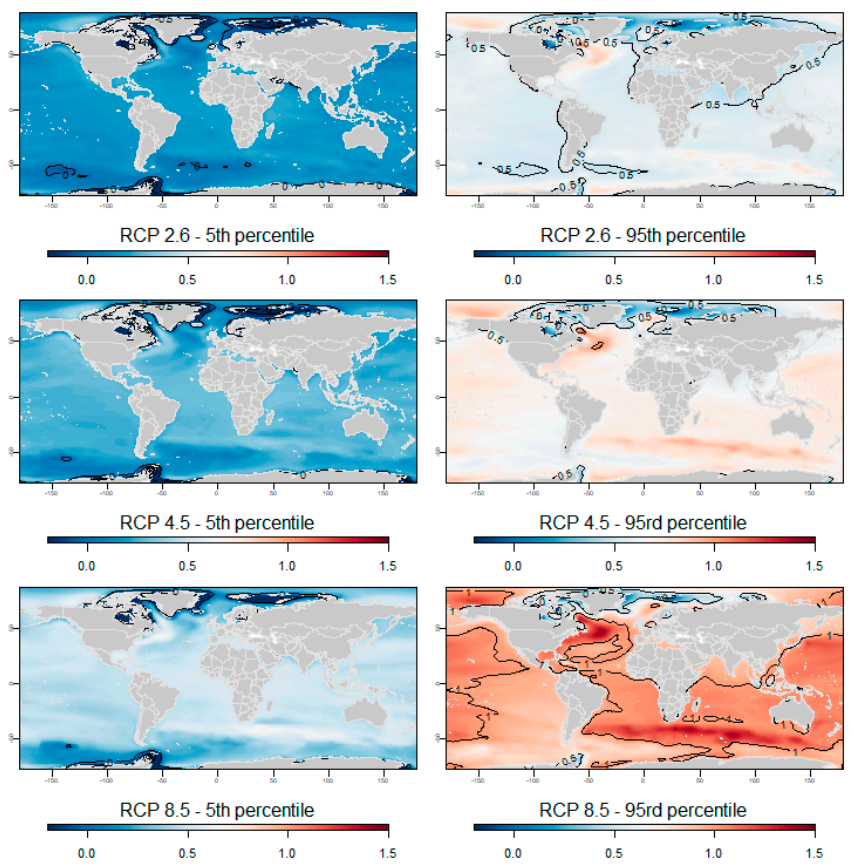

Figure A4. Low-end regional sea-level projections in 2100 for three RCP scenarios with respect to 1985-2006 (5th and 95th percentiles; unit: m). 


\section{References}

1. Church, J.A.; Clark, P.U.; Cazenave, A.; Gregory, J.M.; Jevrejeva, S.; Levermann, A.; Merrifield, M.A.; Milne, G.A.; Nerem, R.S.; Nunn, P.D.; et al. Sea Level Change. In Climate Change 2013: The Physical Science Basis; Contribution of Working Group I to the Fifth Assessment Report of the Intergovernmental Panel on Climate; Cambridge University Press: Cambridge, UK; New York, NY, USA, 2013.

2. Cazenave, A.; Llovel, W. Contemporary Sea Level Rise. Annu. Rev. Mar. Sci. 2010, 2, 145-173. [CrossRef] [PubMed]

3. Stammer, D.; Cazenave, A.; Ponte, R.M.; Tamisiea, M.E. Causes for Contemporary Regional Sea Level Changes. Annu. Rev. Mar. Sci. 2013, 5, 21-46. [CrossRef] [PubMed]

4. Little, C.M.; Horton, R.M.; Kopp, R.E.; Oppenheimer, M.; Yip, S. Uncertainty in Twenty-First-Century CMIP5 Sea Level Projections. J. Clim. 2015, 28, 838-852. [CrossRef]

5. Rignot, E.; Mouginot, J.; Morlighem, M.; Seroussi, H.; Scheuchl, B. Widespread, rapid grounding line retreat of Pine Island, Thwaites, Smith, and Kohler glaciers, West Antarctica, from 1992 to 2011. Geophys. Res. Lett. 2014, 41, 3502-3509. [CrossRef]

6. Ritz, C.; Edwards, T.L.; Durand, G.; Payne, A.J.; Peyaud, V.; Hindmarsh, R.C.A. Potential sea-level rise from Antarctic ice-sheet instability constrained by observations. Nature 2015, 528, 115-118. [CrossRef]

7. Bulthuis, K.; Arnst, M.; Sun, S.; Pattyn, F. Uncertainty quantification of the multi-centennial response of the Antarctic ice sheet to climate change. Cryosphere 2019, 13, 1349-1380. [CrossRef]

8. Jacob, T.; Wahr, J.; Pfeffer, W.T.; Swenson, S. Recent contributions of glaciers and ice caps to sea level rise. Nature 2012, 482, 514-518. [CrossRef]

9. Marzeion, B.; Jarosch, A.H.; Hofer, M. Past and future sea-level change from the surface mass balance of glaciers. Cryosphere 2012, 6, 1295-1322. [CrossRef]

10. Furst, J.J.; Goelzer, H.; Huybrechts, P. Ice-dynamic projections of the Greenland ice sheet in response to atmospheric and oceanic warming. Cryosphere 2015, 9, 1039-1062. [CrossRef]

11. Palerme, C.; Genthon, C.; Claud, C.; Kay, J.E.; Wood, N.B.; L`Ecuyer, T. Evaluation of current and projected Antarctic precipitation in CMIP5 models. Clim. Dyn. 2017, 48, 225-239. [CrossRef]

12. Frieler, K.; Clark, P.U.; He, F.; Buizert, C.; Reese, R.; Ligtenberg, S.R.M.; Van den Broeke, M.R.; Winkelmann, R.; Levermann, A. Consistent evidence of increasing Antarctic accumulation with warming. Nat. Clim. Chang. 2015, 5, 348-352. [CrossRef]

13. Rignot, E.; Casassa, G.; Gogineni, P.; Krabill, W.; Rivera, A.; Thomas, R. Accelerated ice discharge from the Antarctic Peninsula following the collapse of Larsen B ice shelf. Geophys. Res. Lett. 2004, 31. [CrossRef]

14. Llovel, W.; Becker, M.; Cazenave, A.; Jevrejeva, S.; Alkama, R.; Decharme, B.; Douville, H.; Ablain, M.; Beckley, B. Terrestrial waters and sea level variations on interannual time scale. Glob. Planet. Chang. 2011, 75, 76-82. [CrossRef]

15. Wada, Y.; Van Beek, L.P.H.; Weiland, F.C.S.; Chao, B.F.; Wu, Y.H.; Bierkens, M.F.P. Past and future contribution of global groundwater depletion to sea-level rise. Geophys. Res. Lett. 2012, 39. [CrossRef]

16. Meyssignac, B.; Slangen, A.B.A.; Melet, A.; Church, J.A.; Fettweis, X.; Marzeion, B.; Agosta, C.; Ligtenberg, S.R.M.; Spada, G.; Richter, K.; et al. Evaluating Model Simulations of Twentieth-Century Sea-Level Rise. Part II: Regional Sea-Level Changes. J. Clim. 2017, 30, 8565-8593. [CrossRef]

17. Slangen, A.B.A.; Katsman, C.A.; Van de Wal, R.S.W.; Vermeersen, L.L.A.; Riva, R.E.M. Towards regional projections of twenty-first century sea-level change based on IPCC SRES scenarios. Clim. Dyn. 2012, 38, 1191-1209. [CrossRef]

18. Slangen, A.B.A.; Carson, M.; Katsman, C.A.; Van de Wal, R.S.W.; Kohl, A.; Vermeersen, L.L.A.; Stammer, D. Projecting twenty-first century regional sea-level changes. Clim. Chang. 2014, 124, 317-332. [CrossRef]

19. Kopp, R.E.; Horton, R.M.; Little, C.M.; Mitrovica, J.X.; Oppenheimer, M.; Rasmussen, D.J.; Strauss, B.H.; Tebaldi, C. Probabilistic 21st and 22nd century sea-level projections at a global network of tide-gauge sites. Earths Future 2014, 2, 383-406. [CrossRef]

20. Peltier, W.R. Global glacial isostasy and the surface of the ice-age earth: The ice-5G (VM2) model and grace. Annu. Rev. Earth Planet. Sci. 2004, 32, 111-149. [CrossRef]

21. Idier, D.; Paris, F.; Le Cozannet, G.; Boulahya, F.; Dumas, F. Sea-level rise impacts on the tides of the European Shelf. Cont. Shelf Res. 2017, 137, 56-71. [CrossRef] 
22. Melet, A.; Meyssignac, B.; Almar, R.; Le Cozannet, G. Under-estimated wave contribution to coastal sea-level rise. Nat. Clim. Chang. 2018, 8, 234-239. [CrossRef]

23. Zhang, X.B.; Church, J.A.; Monselesan, D.; McInnes, K.L. Sea level projections for the Australian region in the 21st century. Geophys. Res. Lett. 2017, 44, 8481-8491. [CrossRef]

24. Poitevin, C.; Woppelmann, G.; Raucoules, D.; Le Cozannet, G.; Marcos, M.; Testut, L. Vertical land motion and relative sea level changes along the coastline of Brest (France) from combined space-borne geodetic methods. Remote Sens. Environ. 2019, 222, 275-285. [CrossRef]

25. Woppelmann, G.; Marcos, M. Vertical land motion as a key to understanding sea level change and variability. Rev. Geophys. 2016, 54, 64-92. [CrossRef]

26. De Winter, R.C.; Reerink, T.J.; Slangen, A.B.A.; De Vries, H.; Edwards, T.; Van de Wal, R.S.W. Impact of asymmetric uncertainties in ice sheet dynamics on regional sea level projections. Nat. Hazards Earth Syst. Sci. 2017, 17, 2125-2141. [CrossRef]

27. Carson, M.; Kohl, A.; Stammer, D.; Slangen, A.B.A.; Katsman, C.A.; Van de Wal, R.S.W.; Church, J.; White, N. Coastal sea level changes, observed and projected during the 20th and 21st century. Clim. Chang. 2016, 134, 269-281. [CrossRef]

28. Jackson, L.P.; Grinsted, A.; Jevrejeva, S. 21st Century Sea-Level Rise in Line with the Paris Accord. Earths Future 2018, 6, 213-229. [CrossRef]

29. Le Bars, D.; Drijfhout, S.; De Vries, H. A high-end sea level rise probabilistic projection including rapid Antarctic ice sheet mass loss. Environ. Res. Lett. 2017, 12. [CrossRef]

30. Garner, A.J.; Weiss, J.L.; Parris, A.; Kopp, R.E.; Horton, R.M.; Overpeck, J.T.; Horton, B.P. Evolution of 21st Century Sea Level Rise Projections. Earths Future 2018, 6, 1603-1615. [CrossRef]

31. Slangen, A.B.A.; Adloff, F.; Jevrejeva, S.; Leclercq, P.W.; Marzeion, B.; Wada, Y.; Winkelmann, R. A Review of Recent Updates of Sea-Level Projections at Global and Regional Scales. Surv. Geophys. 2017, 38, 385-406. [CrossRef]

32. Clark, P.U.; Shakun, J.D.; Marcott, S.A.; Mix, A.C.; Eby, M.; Kulp, S.; Levermann, A.; Milne, G.A.; Pfister, P.L.; Santer, B.D.; et al. Consequences of twenty-first-century policy for multi-millennial climate and sea-level change. Nat. Clim. Chang. 2016, 6, 360-369. [CrossRef]

33. DeConto, R.M.; Pollard, D. Contribution of Antarctica to past and future sea-level rise. Nature 2016, 531, 591-597. [CrossRef] [PubMed]

34. Edwards, T.L.; Brandon, M.A.; Durand, G.; Edwards, N.R.; Golledge, N.R.; Holden, P.B.; Nias, I.J.; Payne, A.J.; Ritz, C.; Wernecke, A. Revisiting Antarctic ice loss due to marine ice-cliff instability. Nature 2019, 566, 58-64. [CrossRef] [PubMed]

35. Le Bars, D. Uncertainty in Sea Level Rise Projections Due to the Dependence Between Contributors. Earths Future 2018, 6, 1275-1291. [CrossRef]

36. Le Cozannet, G.; Manceau, J.C.; Rohmer, J. Bounding probabilistic sea-level projections within the framework of the possibility theory. Environ. Res. Lett. 2017, 12. [CrossRef]

37. Nicholls, R.J.; Hanson, S.E.; Lowe, J.A.; Warrick, R.A.; Lu, X.F.; Long, A.J. Sea-level scenarios for evaluating coastal impacts. Wiley Interdiscip. Rev. Clim. Chang. 2014, 5, 129-150. [CrossRef]

38. Le Cozannet, G.; Nicholls, R.J.; Hinkel, J.; Sweet, W.V.; McInnes, K.L.; Van de Wal, R.S.W.; Slangen, A.B.A.; Lowe, J.A.; White, K.D. Sea Level Change and Coastal Climate Services: The Way Forward. J. Mar. Sci. Eng. 2017, 5, 49. [CrossRef]

39. Hinkel, J.; Church, J.A.; Gregory, J.M.; Lambert, E.; Le Cozannet, G.; Lowe, J.; McInnes, K.L.; Nicholls, R.J.; Van der Pol, T.D.; Van de Wal, R. Meeting User Needs for Sea Level Rise Information: A Decision Analysis Perspective. Earths Future 2019, 7, 320-337. [CrossRef]

40. Stammer, D.; Van de Wal, R.S.W.; Nicholls, R.J.; Church, J.A.; Le Cozannet, G.; Lowe, J.A.; Horton, B.P.; White, K.; Behar, D.; Hinkel, J. Framework for high-end estimates of sea-level rise for stakeholder applications. Earths Future 2019. [CrossRef]

41. Huss, M.; Hock, R. A new model for global glacier change and sea-level rise. Front. Earth Sci. 2015, 3, 54. [CrossRef]

42. Gregory, J.M.; Griffies, S.M.; Hughes, C.W.; Lowe, J.A.; Church, J.A.; Fukimori, I.; Gomez, N.; Kopp, R.E.; Landerer, F.; Le Cozannet, G.; et al. Concepts and Terminology for Sea Level: Mean, Variability and Change, Both Local and Global. Surv. Geophys. 2019, 1-39. [CrossRef] 
43. Chambers, J.M.; Cleveland, W.S.; Kleiner, B.; Tukey, P.A. Graphical Methods for Data Analysis; Chapman and Hall/CRC: London, UK, 1983; Volume 21.

44. Yin, J.J.; Schlesinger, M.E.; Stouffer, R.J. Model projections of rapid sea-level rise on the northeast coast of the United States. Nat. Geosci. 2009, 2, 262-266. [CrossRef]

45. Jackson, L.P.; Jevrejeva, S. A probabilistic approach to 21st century regional sea-level projections using RCP and High-end scenarios. Glob. Planet. Chang. 2016, 146, 179-189. [CrossRef]

46. Kopp, R.E.; DeConto, R.M.; Bader, D.A.; Hay, C.C.; Horton, R.M.; Kulp, S.; Oppenheimer, M.; Pollard, D.; Strauss, B.H. Evolving Understanding of Antarctic Ice-Sheet Physics and Ambiguity in Probabilistic Sea-Level Projections. Earths Future 2017, 5, 1217-1233. [CrossRef]

47. Radic, V.; Bliss, A.; Beedlow, A.C.; Hock, R.; Miles, E.; Cogley, J.G. Regional and global projections of twenty-first century glacier mass changes in response to climate scenarios from global climate models. Clim. Dyn. 2014, 42, 37-58. [CrossRef]

48. Shannon, S.; Smith, R.; Wiltshire, A.; Payne, T.; Huss, M.; Betts, R.; Caesar, J.; Koutroulis, A.; Jones, D.; Harrison, S. Global glacier volume projections under high-end climate change scenarios. Cryosphere 2019, 13, 325-350. [CrossRef]

49. Hirabayashi, Y.; Zang, Y.; Watanabe, S.; Koirala, S.; Kanae, S. Projection of glacier mass changes under a high-emission climate scenario using the global glacier model HYOGA2. Hydrol. Res. Lett. 2013, 7, 6-11. [CrossRef]

50. Cazenave, A.; Meyssignac, B.; Ablain, M.; Balmaseda, M.; Bamber, J.; Barletta, V.; Beckley, B.; Benveniste, J.; Berthier, E.; Blazquez, A.; et al. Global sea-level budget 1993-present. Earth Syst. Sci. Data 2018, 10, 1551-1590. [CrossRef]

51. Bamber, J.L.; Aspinall, W.P. An expert judgement assessment of future sea level rise from the ice sheets. Nat. Clim. Chang. 2013, 3, 424-427. [CrossRef]

52. Calov, R.; Beyer, S.; Greve, R.; Beckmann, J.; Willeit, M.; Kleiner, T.; Ruckamp, M.; Humbert, A.; Ganopolski, A. Simulation of the future sea level contribution of Greenland with a new glacial system model. Cryosphere 2018, 12, 3097-3121. [CrossRef]

53. Hanna, E.; Fettweis, X.; Hall, R.J. Brief communication: Recent changes in summer Greenland blocking captured by none of the CMIP5 models. Cryosphere 2018, 12, 3287-3292. [CrossRef]

54. Shepherd, A.; Ivins, E.R.; Geruo, A.; Barletta, V.R.; Bentley, M.J.; Bettadpur, S.; Briggs, K.H.; Bromwich, D.H.; Forsberg, R.; Galin, N.; et al. A Reconciled Estimate of Ice-Sheet Mass Balance. Science 2012, 338, 1183-1189. [CrossRef]

55. Dieng, H.B.; Cazenave, A.; Meyssignac, B.; Ablain, M. New estimate of the current rate of sea level rise from a sea level budget approach. Geophys. Res. Lett. 2017, 44, 3744-3751. [CrossRef]

56. Pattyn, F. Sea-level response to melting of Antarctic ice shelves on multi-centennial timescales with the fast Elementary Thermomechanical Ice Sheet model (f.ETISh v1.0). Cryosphere 2017, 22, 1851-1878. [CrossRef]

57. Golledge, N.R.; Kowalewski, D.E.; Naish, T.R.; Levy, R.H.; Fogwill, C.J.; Gasson, E.G.W. The multi-millennial Antarctic commitment to future sea-level rise. Nature 2015, 526, 421-425. [CrossRef]

58. Schlegel, N.J.; Seroussi, H.; Schodlok, M.P.; Larour, E.Y.; Boening, C.; Limonadi, D.; Watkins, M.M.; Morlighem, M.; Van den Broeke, M.R. Exploration of Antarctic Ice Sheet 100-year contribution to sea level rise and associated model uncertainties using the ISSM framework. Cryosphere 2018, 12, 3511-3534. [CrossRef]

59. Lemperiere, F.; Lafitte, R. The role of dams in the XXI Century to achieve a sustainable development target. In Proceedings of the International Symposium on Dams in the Societies of the 21st Century, Barcelona, Spain, 18-23 June 2006; pp. 1065-1072.

60. Gzyl, H. The method of maximum entropy. In Series on Advances in Mathematics for Applied Sciences; Bellomo, F., Brezzi, N., Eds.; World Scientific Publishing Co.: Singapore, 1995; Volume 29, p. 160.

61. Mishra, S. Assigning Probability Distributions to Input Parameters of Performance Assessment Models; INTERA Inc.: Austin, TX, USA, 2002.

62. Meyssignac, B.; Fettweis, X.; Chevrier, R.; Spada, G. Regional Sea Level Changes for the Twentieth and the Twenty-First Centuries Induced by the Regional Variability in Greenland Ice Sheet Surface Mass Loss. J. Clim. 2017, 30, 2011-2028. [CrossRef]

63. Rahmstorf, S.; Foster, G.; Cazenave, A. Comparing climate projections to observations up to 2011. Environ. Res. Lett. 2012, 7. [CrossRef] 
64. Fettweis, X.; Franco, B.; Tedesco, M.; Van Angelen, J.H.; Lenaerts, J.T.M.; Van den Broeke, M.R.; Gallee, H. Estimating the Greenland ice sheet surface mass balance contribution to future sea level rise using the regional atmospheric climate model MAR. Cryosphere 2013, 7, 469-489. [CrossRef]

65. Slater, T.; Shepherd, A. Antarctic ice losses tracking high. Nat. Clim. Chang. 2018, 8, 1025-1026. [CrossRef]

66. Tietjen, G.L.; Moore, R.H. Some Grubbs-Type Statistics for the Detection of Several Outliers. Technometrics 1972, 14, 583-597. [CrossRef]

67. Wilks, S.S. Determination of sample sizes for setting tolerance limits. Ann. Math. Stat. 1941, 12, 91-96. [CrossRef]

68. Rohmer, J.; Manceau, J.; Guyonnet, D.; Boulahya, F. HyRisk: Hybrid Methods for Addressing Uncertainty in Risk Assessments. 2017. Available online: https://cran.r-project.org/web/packages/HYRISK/index.html (accessed on 19 July 2019).

69. Bratley, P.; Fox, B. ALGORITHM 659 Implementing Sobol's Quasirandom Sequence Generator. ACM Trans. Math. Softw. 1988, 14, 88-100. [CrossRef]

70. Hay, C.C.; Morrow, E.; Kopp, R.E.; Mitrovica, J.X. Probabilistic reanalysis of twentieth-century sea-level rise. Nature 2015, 517, 481-484. [CrossRef]

71. Dangendorf, S.; Marcos, M.; Woppelmann, G.; Conrad, C.P.; Frederikse, T.; Riva, R. Reassessment of 20th century global mean sea level rise. Proc. Natl. Acad. Sci. USA 2017, 114, 5946-5951. [CrossRef]

72. Chen, X.Y.; Zhang, X.B.; Church, J.A.; Watson, C.S.; King, M.A.; Monselesan, D.; Legresy, B.; Harig, C. The increasing rate of global mean sea-level rise during 1993-2014. Nat. Clim. Chang. 2017, 7, 492-495. [CrossRef]

73. Riahi, K.; Van Vuuren, D.P.; Kriegler, E.; Edmonds, J.; O’Neill, B.C.; Fujimori, S.; Bauer, N.; Calvin, K.; Dellink, R.; Fricko, O.; et al. The Shared Socioeconomic Pathways and their energy, land use, and greenhouse gas emissions implications: An overview. Glob. Environ. Chang. Hum. Policy Dimens. 2017, 42, 153-168. [CrossRef]

74. Perrette, M.; Landerer, F.; Riva, R.; Frieler, K.; Meinshausen, M. A scaling approach to project regional sea level rise and its uncertainties. Earth Syst. Dyn. 2013, 4, 11-29. [CrossRef]

75. Rockström, J.; Gaffney, O.; Rogelj, J.; Meinshausen, M.; Nakicenovic, N.; Schellnhuber, H.J. A roadmap for rapid decarbonization. Science 2017, 355, 1269-1271. [CrossRef]

76. Iyer, G.C.; Edmonds, J.A.; Fawcett, A.A.; Hultman, N.E.; Alsalam, J.; Asrar, G.R.; Calvin, K.V.; Clarke, L.E.; Creason, J.; Jeong, M.; et al. The contribution of Paris to limit global warming to 2 degrees C. Environ. Res. Lett. 2015, 10, 10. [CrossRef]

77. Nicholls, R.J.; Cazenave, A. Sea-Level Rise and Its Impact on Coastal Zones. Science 2010, 328, 1517-1520. [CrossRef]

78. Nachmany, M.; Mangan, E. Aligning National and International Climate Targets. 2018. Available online: http://www.lse.ac.uk/GranthamInstitute/publication/targets/ (accessed on 19 July 2019).

79. Idier, D.; Bertin, X.; Thompson, P.; Pickering, M.D. Interactions Between Mean Sea Level, Tide, Surge, Waves and Flooding: Mechanisms and Contributions to Sea Level Variations at the Coast. Surv. Geophys. 2019. [CrossRef]

80. Haigh, I.; Green, M.; Pickering, M.; Arbic, B.; Arns, A.; Dangendorf, S.; Hill, D.; Horsburgh, K.; Howard, T.; Idier, D.; et al. The Tides They Are a-Changin. Rev. Geophys. 2019.

81. Vousdoukas, M.I.; Mentaschi, L.; Voukouvalas, E.; Verlaan, M.; Jevrejeva, S.; Jackson, L.P.; Feyen, L. Global probabilistic projections of extreme sea levels show intensification of coastal flood hazard. Nat. Commun. 2018, 9, 2360. [CrossRef]

82. Han, W.Q.; Meehl, G.A.; Stammer, D.; Hu, A.X.; Hamlington, B.; Kenigson, J.; Palanisamy, H.; Thompson, P. Spatial Patterns of Sea Level Variability Associated with Natural Internal Climate Modes. Surv. Geophys. 2017, 38, 217-250. [CrossRef]

83. Nicholls, R.J.; Marinova, N.; Lowe, J.A.; Brown, S.; Vellinga, P.; De Gusmao, D.; Hinkel, J.; Tol, R.S.J. Sea-level rise and its possible impacts given a 'beyond 4 degrees $C$ world' in the twenty-first century. Philos. Trans. $R$. Soc. A Math. Phys. Eng. Sci. 2011, 369, 161-181. [CrossRef]

(C) 2019 by the authors. Licensee MDPI, Basel, Switzerland. This article is an open access article distributed under the terms and conditions of the Creative Commons Attribution (CC BY) license (http://creativecommons.org/licenses/by/4.0/). 